\title{
The Dispersion of Nanometer SiC on Electroless Ni-P-nano SiC Composite Plating
}

\author{
Hong Wang*, Yubao Cao and Wenqing Wei \\ Weifang University, School of Mechanical-electronic and Vehicle Engineering, Weifang, Shandong, China \\ ${ }^{*}$ Corresponding author
}

\begin{abstract}
In recent years, along with the development of nanometer material and technology, it is raising the upsurge of researching the craft of electroless composite plating with nanometer particles in domestic and foreign. However the nanometer material because its big relative surface proportion, the increase of superficial atomicity, insufficient of atomic coordinate, and the high surface energy, make these superficial atoms to have the higher activeness, they are extremely unstable and very easy to reunite with each other and become the big reunion body with some connection interfaces. Therefore, in order to make the nanometer particles suspend evenly in the bath to obtain the composite coating of symmetrical distribution of nanometer particles, the question of dispersion of nanometer particles appears important especially. The orthogonal test method has been used to study the effects of the concentration of $\mathrm{SiC}$, the speed of mixing, the temperature and the surfactants on depositing rate and micro-hardness, and obtained the optimized technological scheme and fine Ni-P-SiC composite coating. The results showed that using citric acid-acetic acid as complexing agents can obtain high speed of depositing and homogeneous coating with SiC well-distributed. Among the technological parameters, the effects of temperature on depositing rate is biggest, and the surfactants is next; the effects of the concentration of $\mathrm{SiC}$ particles on micro-hardness is biggest, and the surfactants is next. Give consideration to depositing rate and stability of the liquid, the temperature should be controlled at $82 \pm 2^{\circ} \mathrm{C}$, the concentration of $\mathrm{SiC}$ particles and surfactants should be controlled in $4 \mathrm{~g} / \mathrm{L}$ and $60 \mathrm{mg} / \mathrm{L}$. The influence to microhardness value of coating with ultrasonic disperser craft also has been studied.
\end{abstract}

Keywords-electroless composite plating; nanometer SiC; disperser; ultrasonic; surfactant; speed of mixing

\section{INTRODUCTION}

With the rapid development of aviation, aerospace, electronic, mechanical, chemical and nuclear energy, a variety of new functional and structural materials are becoming urgent need, and some single material can not meet some special requirements, therefore, composite materials have been developed rapidly. Composite plating, also known as spreadplated, composite coatings with wear and corrosion resistance were deposited on the surface of metal matrix layer by electroplating or electroless composite plating to achieve longer life, saving material, reducing costs and improving economic efficiency.

Electroless composite plating is a more convenient and economical way for preparation of composite coating, easy to operate, less investment in equipment, easy to control, low energy consumption. This paper uses a way of adding single $\mathrm{SiC}$ wear particles to the Ni-P alloy bath, deposites wear and corrosion Ni-P-SiC composite coating on the surface of 45 steel by electroless composite plating that can be used for piston rings, cylinder liners, molds, bearings, crankshaft and other mechanical parts, extending its life.

\section{EXPERIMENT}

A. Experimental Instrument and Materials

Experimental instrument is shown in Table I.

TABLE I. EXPERIMENTAL INSTRUMENT

\begin{tabular}{|c|c|}
\hline Instrument name & Specification \\
\hline $\begin{array}{c}\text { Collector constant } \\
\text { temperature heating } \\
\text { magnetic stirrer }\end{array}$ & DF-101S \\
\hline $\begin{array}{c}\text { Desktop CNC ultrasonic } \\
\text { cleaner }\end{array}$ & KQ5200DB \\
\hline PH meter & FE20K \\
\hline $\begin{array}{c}\text { Electronic Analytical } \\
\text { Balance }\end{array}$ & AR423CN \\
\hline Vickers Hardness Tester & HVS-10 \\
\hline
\end{tabular}

Use the ordinary carbon structural steel plate Q235 as sample, Size $(\mathrm{L} \times \mathrm{W} \times \mathrm{H})$ is $15 \mathrm{~mm} \times 15 \mathrm{~mm} \times 2 \mathrm{~mm}$, producted by Weifang red flag Machinery Factory. Before plating pretreatment of the sample must be carried out whose process is described below.

Chemical degreasing $\rightarrow$ Rinse with distilled water $\rightarrow$ Ultrasonic cleaning $\rightarrow$ Rinse with distilled water $\rightarrow 10 \% \mathrm{HCl}$ Activating (1-2min) $\rightarrow$ Rinse with distilled water.

Bath components are selected according to the results of a large number of single-factor test, The composition of plating solution is shown in Table II.

The physics performance of nano-SiC particles used in this study is indicated in Table III. 
TABLE II. THE COMPOSITION OF PLATING SOLN

\begin{tabular}{|c|c|c|c|c|c|c|c|}
\hline Composition & $\mathbf{N i S O}_{4} \cdot \mathbf{6 H}_{2} \mathbf{O}[\mathrm{g} / \mathrm{L}]$ & $\mathbf{N a H}_{2} \mathbf{P O}_{2} \cdot \mathbf{H}_{2} \mathbf{O}[\mathbf{g} / \mathbf{L}]$ & $\begin{array}{c}\mathrm{Na}_{3} \mathrm{C}_{\mathrm{it}} \cdot \mathbf{H}_{2} \mathbf{O} \\
{[\mathrm{g} / \mathrm{L}]}\end{array}$ & $\begin{array}{c}\mathbf{C H}_{3} \mathbf{C O O N a} \\
{[\mathrm{g} / \mathrm{L}]}\end{array}$ & $\begin{array}{c}\text { Accelerant } \\
{[\mathrm{g} / \mathrm{L}]}\end{array}$ & $\begin{array}{c}\text { Stabilizer } \\
{[\mathrm{mg} / \mathrm{L}]}\end{array}$ & $\begin{array}{c}\mathbf{N a n o} \mathrm{SiC} \\
{[\mathrm{g} / \mathrm{L}]}\end{array}$ \\
\hline Content & 25 & 30 & 35 & 5 & 5 & 5 & \\
\hline
\end{tabular}

TABLE III. PHYSICS PERFORMANCE OF THE NANOMETER PARTICLE OF SIC

\begin{tabular}{|c|c|c|c|c|c|c|c|}
\hline $\begin{array}{c}\text { Average size } \\
{[\mathbf{n m}]}\end{array}$ & $\begin{array}{c}\text { Surface area } \\
{\left[\mathbf{m}^{2} / \mathbf{g}\right]}\end{array}$ & Crystal & Color & $\begin{array}{c}\text { Free silicon } \\
{[\%]}\end{array}$ & $\begin{array}{c}\text { Total oxygen } \\
\text { content [\%] }\end{array}$ & $\begin{array}{c}\text { Purity [\%] } \\
\text { Bulk density } \\
{\left[\mathbf{g} / \mathbf{c m}^{\mathbf{3}}\right]}\end{array}$ \\
\hline 40 & 90 & Cubic structure & Gray-green & $<0.2$ & $<0.61$ & $>99.09$ & 0.05 \\
\hline
\end{tabular}

\section{B. Test Method}

The plating speed is indicated by the coating weight gain per unit area and per unit time. First, clean degrease the substrate, and then weigh on analytical balance in the parts per million, record the quality $\mathrm{m}_{1}$. After plating, clean degrease the sample, and then weigh on analytical balance in the parts per million again and record the quality $\mathrm{m}_{2}$. Plating rate is calculated by equation 1 .

$$
V=\frac{m_{2}-m_{1}}{S \times t}
$$

Formula S-Plating area $\left(\mathrm{m}^{2}\right)$

t-Plating time (h)

Experiments load applied is $100 \mathrm{~g}$, loading time is $15 \mathrm{~s}$. Select three different locations in the coating surface to test their hardness, calculate the average hardness by the online system using Equation 2.

$$
\mathrm{HV}=1854.5 \times \mathrm{F} \div \mathrm{D} 2
$$

Formula HV-Vickers microhardness symbol $\left(\mathrm{Kgf} / \mathrm{mm}^{2}\right)$

F-The load applied to the specimen (g)

D-Diagonal $(\mu \mathrm{m})$

The $\mathrm{L}_{9}{ }^{3}$ orthogonal table has been used to study the effects of the concentration of $\mathrm{SiC}$, the speed of mixing, the temperature and the surfactants on depositing rate and microhardness. Each factor is tested by three levels, experimental factors and levels are shown in Table IV.

TABLE IV. ORTHOGONAL FACTORS AND LEVEL

\begin{tabular}{|c|c|c|c|c|}
\hline $\begin{array}{c}\text { Factors } \\
\text { level }\end{array}$ & $\begin{array}{c}\text { Concentration } \\
\text { of SiC }[\mathbf{g} / \mathbf{L}]\end{array}$ & $\begin{array}{c}\text { Speed of } \\
\text { mixing } \\
{[\mathbf{r} / \mathbf{m i n}]}\end{array}$ & $\begin{array}{c}\text { Surfactant } \\
{[\mathbf{m g} / \mathbf{L}]}\end{array}$ & $\begin{array}{c}\text { Temperature } \\
{\left[{ }^{\circ} \mathbf{C}\right]}\end{array}$ \\
\hline 1 & 6 & 200 & 30 & 77 \\
\hline 2 & 4 & 250 & 60 & 82 \\
\hline 3 & 2 & 300 & 90 & 87 \\
\hline
\end{tabular}

The surface and cross-section morphology of composite coatings were identified by QUANTA200 environmental scanning electron microscopy (SEM) under the test condition of accelerating voltage $3.0 \mathrm{kV}$. Elements of composite coatings were determined by their micro-scanning using INCA ENERGY 300 X-ray energy dispersive spectroscopy (EDS) under the test condition of accelerating voltage of $25 \mathrm{kV}$.

\section{TESt RESUlTS AND DisCUSSION}

\section{A. The Influence of Factor on Depositing Rate and Analysis}

The influence of factor on depositing rate and analysis is shown in Table V.

Table $\mathrm{V}$ shows the the analysis results that within the scope of this experiment, temperature is a major factor in the coating deposition rate, surfactant concentration is a secondary factor affecting the plating rate, stirring speed and amount of $\mathrm{SiC}$ is little effect to plating rate.

\begin{tabular}{|c|c|c|c|c|c|}
\hline Factor Level & $\begin{array}{c}\text { Concentration of } \mathrm{SiC} \\
{[\mathrm{g} / \mathrm{L}]}\end{array}$ & $\begin{array}{c}\text { Speed of mixing } \\
{[\mathbf{r} / \mathbf{m i n}]}\end{array}$ & Surfactant [mg/L] & Temperature $\left[{ }^{\circ} \mathrm{C}\right]$ & $\begin{array}{c}\text { Depositing rate } \\
{\left[\mathrm{g} / \mathbf{m}^{2} \mathbf{h}\right]}\end{array}$ \\
\hline 1 & 1 & 1 & 1 & 1 & 46.667 \\
\hline 2 & 1 & 2 & 2 & 2 & 47.222 \\
\hline 3 & 1 & 3 & 3 & 3 & 49.060 \\
\hline 4 & 2 & 3 & 2 & 1 & 37.778 \\
\hline 5 & 2 & 1 & 3 & 2 & 53.333 \\
\hline 6 & 2 & 2 & 1 & 3 & 60.556 \\
\hline 7 & 3 & 2 & 3 & 1 & 29.445 \\
\hline 8 & 3 & 3 & 1 & 2 & 94.445 \\
\hline 9 & 3 & 1 & 2 & 3 & 78.472 \\
\hline $\mathrm{R} 1$ & 47.650 & 59.491 & 67.223 & 37.964 & \\
\hline $\mathrm{R} 2$ & 50.556 & 45.741 & 54.491 & 65.000 & \\
\hline R3 & 67.454 & 60.428 & 43.946 & 62.696 & \\
\hline Differential & 19.804 & 14.687 & 23.277 & 27.036 & \\
\hline
\end{tabular}

TABLE V. THE INFLUENCE OF FACTOR ON DEPOSITING RATE AND ANALYSIS 


\section{B. The Influence of Factor on Micro-hardness and Analysis}

The influence of factor on micro-hardness and analysis is shown in Table VI.

Table VI shows the the analysis results that within the scope of this experiment, the amount of $\mathrm{SiC}$ is the main factors impacting coating microhardness, the content of surfactant is the secondary factor affecting coating microhardness.

TABLE VI. THE INFLUENCE OF FACTOR ON MICRO-HARDNESS AND ANALYSIS

\begin{tabular}{|c|c|c|c|c|c|}
\hline $\begin{array}{c}\text { Factor } \\
\text { Level } \\
\text { No. }\end{array}$ & $\begin{array}{c}\text { Concentrat } \\
\text { ion of } \\
\text { SiC[g/L] }\end{array}$ & $\begin{array}{c}\text { Speed of } \\
\text { mixing } \\
{[\mathbf{r} / \mathbf{m i n}]}\end{array}$ & $\begin{array}{c}\text { Surfact } \\
\text { ant } \\
{[\mathbf{m g} / \mathbf{L}]}\end{array}$ & $\begin{array}{c}\text { Tempe } \\
\text { rature } \\
{\left[{ }^{\circ} \mathbf{C}\right]}\end{array}$ & $\begin{array}{c}\text { Micro- } \\
\text { hardness } \\
{\left[\mathbf{H V}_{\mathbf{0 . 1}}\right]}\end{array}$ \\
\hline 1 & 1 & 1 & 1 & 1 & 268 \\
\hline 2 & 1 & 2 & 2 & 2 & 600 \\
\hline 3 & 1 & 3 & 3 & 3 & 390 \\
\hline 4 & 2 & 3 & 2 & 1 & 460 \\
\hline
\end{tabular}

C. Surface Morphologres and Composition Analysis

It can be seen from Figure I, composite coating with uniform and dense dispersed small $\mathrm{SiC}$ particles.

Figure II and Table VII showed that the Chemical Constituents were different between the region $\mathrm{A}$ and $\mathrm{B}$ of composite coatings. The element contents of $\mathrm{C}$ and $\mathrm{Si}$ in the place of A were significantly higher than B. There were small $\mathrm{SiC}$ particles in the region $\mathrm{A}$.

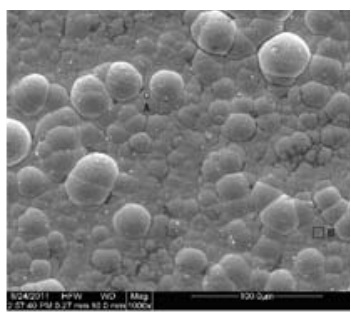

(A)

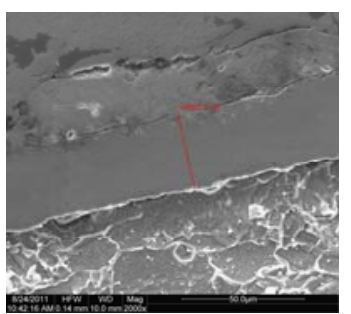

(B)
FIGURE I. CROSS-SECTION AND SURFACE MORPHOLOGY OF COMPOSITE COATINGS (A) SURFACE MORPHOLOGY (B) CROSS-SECTION MORPHOLOGY

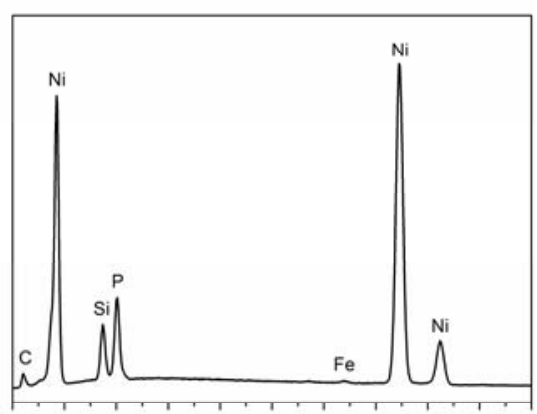

Energy (keV)

(A)

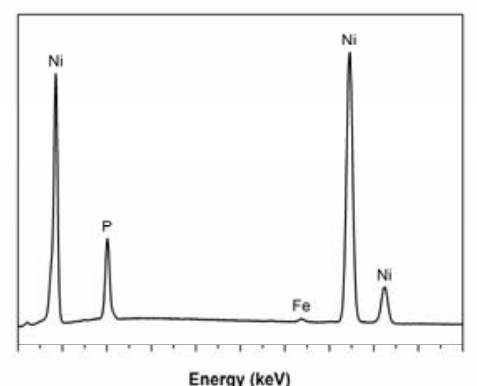

(B)

FIGURE II. EDS PATTERNS OF DIFFERENT POSITIONS ON COMPOSITE COATINGS IN FIGURE I

TABLE VII. THE INFLUENCE OF FACTOR ON MICRO-HARDNESS AND ANALYSIS

\begin{tabular}{|c|c|c|c|c|c|}
\hline \multicolumn{2}{|c|}{ ELEMENT } & NI & P & SI & C \\
\hline $\begin{array}{c}\text { POSITION } \\
\text { A }\end{array}$ & WEIGHT\% & 73.94 & 12.48 & 4.02 & 9.56 \\
\cline { 2 - 6 } & ATOMIC \% & 48.41 & 15.49 & 5.50 & 30.59 \\
\hline $\begin{array}{c}\text { POSITION } \\
\text { B }\end{array}$ & WEIGHT\% & 85.77 & 14.23 & & \\
\cline { 2 - 6 } & ATOMIC \% & 76.07 & 23.93 & & \\
\hline
\end{tabular}

\section{SUMMARY}

The results showed that using citric acid-acetic acid as complexing agents can obtain high speed of depositing and homogeneous coating with $\mathrm{SiC}$ well-distributed. Among the technological parameters, the effects of temperature on depositing rate is biggest, and the mixing speed is next; the effects of the concentration of $\mathrm{SiC}$ particles on micro-hardness is biggest, and the mixing speed is next. Give consideration to depositing rate and stability of the liquid, the temperature should be controlled at $82 \pm 2^{\circ} \mathrm{C}$, the concentration of $\mathrm{SiC}$ particles and surfactants should be controlled in $4 \mathrm{~g} / \mathrm{L}$ and $60 \mathrm{mg} / \mathrm{L}$.

\section{ACKNOWLEDGMENT}

This work was financially supported by Shandong Province Natural Science Foundation Funded Projects(ZR2011EL003) and the Science and Technology Projects of Shandong Education Department (J11LD56).

\section{REFERENCES}

[1] S. G. Chen: submitted to Journal of Thermal processing, Vol. 12 (2005)

[2] Z. J. Guo and J. J. Zhou: submitted to Journal of Petrochemical Corrosion and Protection, Vol. 15 (2000)

[3] G. R. Yang, Y. Ma, X. M. Zhang and Y. Hao: submitted to Journal of Materials Protection, Vol. 42 (2009)

[4] Q. M. Feng, Z. B. Liu and Y. Liu: submitted to Joumal of Xi' an Polytechnic University, Vol. 24 (2010)

[5] X. L. Liu, Y. Y. Liu, H. Huang, N. Leng and X. L. Dong: submitted to Joumal of Materials for Mechanical Engineering, Vol. 32 (2008)

[6] Y. Z. Jin, J. G. Deng, D. L. Liu and X. G. Zeng: submitted to Joumal of Sichuan University of Science \& Engineering (Natural Science Edition), Vol. 23 (2010) .

[7] Y. Y. Wu, C. S. Dai, Y. Z. Zhang and X. G. Hu: submitted to Joumal of Plating and Environmental Protection, Vol. 17 (1997). 